\title{
Ribonucleotide reductase (RNR) of Corynebacterium glutamicum ATCC 13032 - genetic characterization of a second class IV enzyme
}

\author{
Wulf Oehlmann and Georg Auling \\ Author for correspondence: Georg Auling. Fax: +49511 7625287. \\ e-mail : auling@mbox.ifmb.uni-hannover.de
}

Institut für Mikrobiologie, Universität Hannover. Schneiderberg 50, D-30167 Hannover, Germany

\begin{abstract}
Ribonucleotide reductases (RNRs) encoded by nrd (nucleotide reduction) genes are unique enzymes providing the DNA precursors in all living organisms and several viruses. The designation of four classes of RNRs reflects their use of diverse metallo-cofactors. Using oligonucleotide primers derived from conserved domains of the primary structure of known NrdA and NrdE proteins, an internal 938 bp fragment of the nrdE gene was amplified from genomic DNA of Corynebacterium g/utamicum. With this PCR product a $4.36 \mathrm{~kb}$ fragment was identified and cloned containing the nrdHIE genes of $C$. glutamicum. A probe derived from nrdF2 of Mycobacterium tuberculosis allowed the cloning and sequencing of the nrdF gene located 3.1 kb further downstream, encoding the small subunit of the C. glutamicum RNR. Conjugative introduction of nrdE from $C$. glutamicum complemented thermosensitive mutants of Corynebacterium ammoniagenes which had a defective catalytic subunit of the Mn-RNR. The authors provide arguments for allocation of the C. glutamicum NrdEF proteins to class IV in the RNR classification scheme of Stubbe \& van der Donk (1995) [Chem Biol 2, 793-801].
\end{abstract}

Keywords: Corynebacterium glutamicum, $n r d H I E$ genes, distal $n r d F$ gene, heterologous genetic complementation of $n r d^{\text {ts }}$ mutants, Mn-RNR of C. ammoniagenes

\section{INTRODUCTION}

It is now widely accepted that the biochemical evolution from the ancient RNA world to the present-day DNA world created a universal de novo route of DNA precursor biosynthesis (Follmann, 1982; Harder, 1993; Jordan \& Reichard, 1998) for all living organisms, with the ribonucleotide reductases (RNRs) as key enzymes. These complex enzymes catalyse the irreversible deoxygenation of ribonucleoside $5^{\prime}$ - di- or triphosphates to the corresponding $2^{\prime}$-deoxyribonucleotides concomitant

\footnotetext{
Abbreviations: $n r d$, nucleotide reduction; R1, large catalytic subunit of the RNRs encoded by $n r d A ; R 2$, small metal-containing subunit of the RNRs encoded by $n r d B$; R1E, large catalytic subunit of the RNRs encoded by $n r d E$; R2F, small metal-containing subunit of the RNRs encoded by nrdF; RNR, ribonucleotide reductase.

The GenBank accession numbers for the sequences reported in this paper are AF112535 for nrdHIE and AF112536 for nrdF of C. glutamicum ATCC 13032.
}

with the oxidation of a pair of thiol groups to disulfide in thioredoxin or other small proteins with redox-active thiols (Reichard, 1993). The observation that the same principle of allosteric regulation is encountered in all RNRs is a strong argument for the monophyletic origin of ribonucleotide reduction originally suggested by Follmann (1982). A radical mechanism is involved in this enzymic reaction and nature has combined the ability to reduce ribonucleotides with a diverse array of metallo-cofactors in different organisms in order to generate a transient protein radical that initiates nucleotide reduction (Stubbe \& van der Donk, 1995). Thus trace elements like $\mathrm{Co}, \mathrm{Fe}$ and $\mathrm{Mn}$ control growth and DNA production in diverse prokaryotic and eukaryotic organisms (Hogenkamp \& McFarlan, 1984; Lammers \& Follmann, 1983; Harder, 1993). The aerobic Fe-RNR of Escherichia coli, thought to represent the 'genuine' RNR of the Enterobacteriaceae, is the prototype of the class I enzymes consisting of the subunits R1 and R2 which are encoded by the genes $\operatorname{nrdAB}$ (Carlson et al., 
1984). The Mn-RNR of Corynebacterium ammoniagenes ( $\alpha \beta_{2}$ holoenzyme; Willing et al., 1988), represents the prototype of the class IV enzymes in the biochemical classification scheme of Stubbe \& van der Donk (1995) and is designated as class Ib enzyme by Reichard (1993). The metallo-cofactor of this Mn-RNR contains a stable free radical (Griepenburg $e t$ al., 1996) interacting only weakly with its intrinsic metal centre, a mononuclear, isolated $\mathrm{Mn}(\mathrm{II})$ site (Griepenburg, 1998). Independent studies confirmed that the active C. ammoniagenes $\mathrm{Mn}$ RNR contains manganese and, in essence, lacks iron (Fieschi et al., 1998). The $n r d E F$ genes encoding the subunits R1E and R2F of this enzyme have been cloned recently (Fieschi et al., 1998; Oehlmann et al., 1998).

Coryneform bacteria sensu stricto and sensu lato (Liebl, 1992) are important industrial organisms for large-scale production of primary metabolites, namely amino acids and flavour-enhancing substances. The necessity of manganese deprivation as a prerequisite for inosine monophosphate production with C. ammoniagenes can be traced back (Auling \& Follmann, 1994) to the MnRNR described above. However, the status of DNA precursor biosynthesis in the so-called glutamic acid bacteria (Kinoshita, 1985), well-known for large-scale production of amino acids, is not known. Merely, cell elongation of Corynebacterium glutamicum (and similar strains named Brevibacterium divariaticum and $B$. lactofermentum but now allocated to C. glutamicum) was reported to occur under conditions of $\mathrm{Mn}^{2+}$ deficiency (Oka et al., 1968). This is reminiscent of the phenomenon of unbalanced growth death known from the closely related species C. ammoniagenes, which uses the Mn-RNR as class IV enzyme for its DNA precursor biosynthesis (Auling \& Follmann, 1994).

In order to define the principles of manganese binding in the unusual Mn-RNR of coryneform bacteria on a broader basis the study of another class IV enzyme from this group of industrial micro-organisms was of interest. Here we report the cloning and sequencing of the $n r d$ genes of C. glutamicum encoding the key enzyme of DNA precursor biosynthesis in this amino-acid-producing species.

\section{METHODS}

Bacterial strains, plasmids, and culture conditions. The strains and plasmids used in this study are listed in Table 1. Strains were grown aerobically in Luria-Bertani broth containing $10 \mathrm{~g}$ tryptone, $5 \mathrm{~g}$ yeast extract and $5 \mathrm{~g} \mathrm{NaCl}$ per litre $(\mathrm{pH} 7.2)$ at 120 r.p.m. and at $37^{\circ} \mathrm{C}($ E. coli $)$ or $30^{\circ} \mathrm{C}$ (corynebacterial strains). Strains harbouring plasmids were cultured in the presence of the selective antibiotic $\left(50 \mu \mathrm{g} \mathrm{l}^{-1}\right)$.

DNA isolation and manipulation. Plasmid DNA was isolated according to the method of Birnboim \& Doly (1979) and total DNA according to Ausubel et al. (1990). Corynebacteria were pretreated by shaking in lysis buffer containing $30 \mathrm{mg}$ lysozyme $\mathrm{ml}^{-1}$ for $1 \mathrm{~h}$ (plasmid DNA) or $3 \mathrm{~h}$ (total DNA) at $37^{\circ} \mathrm{C}$. DNA-manipulating enzymes were purchased from Boehringer Mannheim, BRL Life Technologies and Qiagen. DNA fragments were isolated from $0.8 \%$ agarose gels using the QiaexII kit (Qiagen). Southern hybridizations were carried out by standard methods (Sambrook et al., 1989). Labelling of probes with digoxigenin-coupled dUTP (Boehringer) was done by PCR.

PCR amplification of the probes used for cloning. For amplification of an internal part of the $n r d E$ gene of $C$. glutamicum, degenerate primers (Biometra) were designed from two conserved peptide sequences (SNLCXEI; LYYXR) of the NrdA and NrdE proteins, respectively (Fig. 1), namely primer P1, 5'-AGC AAC CTG TGC TCG GAG AT-3', and primer P2, 5'-CGC AGC CGG ATG TAG TAC AG-3'. Taq polymerase from Appligene Oncor was used for PCR. Samples of $50 \mu$ l, overlaid with the same volume of paraffin oil, were prepared according to the manufacturer's instructions. Before adding $T a q$ polymerase the mixture was heated at $94^{\circ} \mathrm{C}$ for $5 \mathrm{~min}$ followed by 30 cycles of the following programme: $1 \mathrm{~min}$ at $94^{\circ} \mathrm{C}, 45 \mathrm{~s}$ at $45^{\circ} \mathrm{C}$ and $1 \mathrm{~min}$ at $70^{\circ} \mathrm{C}$. In order to generate a probe for the gene of the small subunit of $C$. glutamicum the $n r d F$ genes of Mycobacterium tuberculosis were amplified with the above PCR protocol but at an increased annealing temperature of $51^{\circ} \mathrm{C}$. The primers used were P3 (5'-ATG ACC GGC AAG CTC GT- $\left.3^{\prime}\right)$ and P4 (5'GAA GTC CCA GTC GGT GT-3') for $n r d F 1$, and P5 $\left(5^{\prime}-\right.$ GTG ACT GGA AAC GCA AA-3') and P6 (5'-GAA GTC CCA GTC ATC GT- $3^{\prime}$ ) for $n r d F 2$, respectively.

Screening of a $C$. glutamicum cosmid library and cloning of the nrd genes. For cloning of the $n r d$ genes of C. glutamicum a cosmid library containing chromosomal DNA fragments of C. glutamicum ATCC 13032 with a size of $40 \mathrm{~kb}$ was used (Bathe et al., 1996). A total of 576 clones were grown in numerical arrangement as single colonies on Nytran membranes (Schleicher \& Schuell) placed on LB agar. Positive clones were identified by colony hybridization (Sambrook et al., 1989) using the probes described above. After digestion with the restriction endonucleases BamHI, EcoRI, HindIII, $K p n \mathrm{I}, P_{s t} \mathrm{I}$, SalI and $\mathrm{Xba \textrm {I }}$ the cosmid named 810 was chosen for final cloning.

Sequencing and sequence analysis. Plasmid pWCG3 containing the nrdHIE genes of C. glutamicum was separately digested with EcoRI and PstI. The isolated fragments of the 4-36 XbaI-Bam HI insert were subcloned into pUC18, resulting in plasmids pWCG2, pWCG32, pWCG35 and pWCG36 (Table 1). In order to sequence $n r d F$ the two positive PstI fragments $(0.93$ and $1.31 \mathrm{~kb})$ obtained after Southern blotting were cloned into pUC18. The two resulting plasmids were named pWCG51 and pWCG52 (Table 1, Fig. 3). Standard primers were used for the sequencing reaction. Primer walking allowed closure of gaps in the double-strand sequence of $n r d H I E$ and $n r d F$. DNA was sequenced with the Dye Terminator Cycle Sequencing Ready Reaction Kit (Applied Biosystems) using an ABI Prism 310 Genetic Analyzer. The BLAST e-mail server at the National Center for Biotechnology Information (NCBI) was used for comparison of sequences.

Genetic complementation of mutants. In order to complement the $n r d E^{\text {ts }}$ mutants $\mathrm{CH} 31$ and $\mathrm{CH} 33$ derived from C. ammoniagenes (Luo et al., 1997) with the $\operatorname{rrdE}$ gene of C. glutamicum, the $4.36 \mathrm{~kb} \mathrm{XbaI-BamHI}$ fragment was excised from $\mathrm{pWCG} 3$ and ligated to the E. coli-C. glutamicum shuttle vector pECM2 (Schäfer et al., 1990). The resulting plasmid pWCG6 was transformed into the mobilizing E. coli strain S17-1 by the method of Sambrook et al. (1989). This donor was then used in conjugation experiments exactly as described by Schäfer et al. (1990). Prior to mating, the recipients $\mathrm{CH} 31$ and $\mathrm{CH} 33$ were treated for $9 \mathrm{~min}$ at $48{ }^{\circ} \mathrm{C}$ in order to enhance the number of transconjugants (Schäfer et al., 1994). After antibiotic selection, single colonies of transconjugants were 
Table 1. Bacterial strains and plasmids

\begin{tabular}{|c|c|c|}
\hline Strain or plasmid & Genotype or description & Source or reference \\
\hline \multicolumn{3}{|l|}{ Bacteria } \\
\hline C. glutamicum ATCC 13032 & Wild-type & American Type Culture Collection \\
\hline C. glutamicum R163 & $\begin{array}{l}\text { Restriction-deficient mutant of C. } \\
\text { glutamicum ATCC } 13059\end{array}$ & Liebl \& Schein $(1990)$ \\
\hline C. ammoniagenes ATCC 6872 & Wild-type & Laboratory stock \\
\hline C. ammoniagenes $\mathrm{CH} 31$ and $\mathrm{CH} 33$ & $n r d E^{\text {ts }}$ mutants of ATCC 6872 & Luo et al. (1997) \\
\hline E. coli $\mathrm{S} 17-1$ & $\begin{array}{l}\text { Mobilizing donor strain, pro } \operatorname{rec} A \text {, which } \\
\text { has an RP4 derivative integrated into the } \\
\text { chromosome }\end{array}$ & Simon et al. (1983) \\
\hline E. coli XL1Blue & $\Delta(m c r A) 183 \Delta(m c r C B-h s d S M R-m r r) 173$ & Jerpseth et al. (1993) \\
\hline \multicolumn{3}{|l|}{ Plasmids } \\
\hline pUC18/19 & $A p^{r}$ & Yanisch-Perron et al. (1985) \\
\hline pECM2 & $\begin{array}{l}\text { Mobilizable E. coli-Corynebacterium } \\
\text { shuttle vector, } \mathrm{Km}^{\mathrm{r}} \mathrm{Cm}^{\mathrm{r}}\end{array}$ & Schäfer et al. (1990) \\
\hline pWCG2 & pUC18 with $1.25 \mathrm{~kb}$ EcoRI insert & This work \\
\hline pWCG3 & pUC18 with $4.36 \mathrm{~kb} \mathrm{Xbal-BamHI}$ insert & This work \\
\hline pWCG32 & pUC18 with $1.87 \mathrm{~kb}$ EcoRI insert & This work \\
\hline pWCG35 & pUC18 with $1.03 \mathrm{~kb}$ PstI insert & This work \\
\hline pWCG36 & pUC18 with $1.16 \mathrm{~kb}$ PstI insert & This work \\
\hline pWCG51 & pUC18 with $0.93 \mathrm{~kb}$ PstI insert & This work \\
\hline pWCG52 & pUC18 with $1.31 \mathrm{~kb}$ PstI insert & This work \\
\hline pWCG6 & pECM2 with $4.36 \mathrm{XbaI}-\mathrm{Bam} \mathrm{HI}$ insert & This work \\
\hline
\end{tabular}

picked and spread onto two plates for a $2 \mathrm{~d}$ incubation at $30^{\circ} \mathrm{C}$ and $37^{\circ} \mathrm{C}$, respectively.

\section{RESULTS}

\section{Cloning the genes nrdHIE and nrdF of C. glutamicum}

Our cloning strategy was based on the assumption that the genes of the two subunits of the C. glutamicum RNR would be located in close proximity, as in other bacterial nrd operons known when our study was initiated (Carlson et al., 1984; Jordan et al., 1994). A comparison of the primary structures of known $\mathrm{NrdA}$ and $\mathrm{NrdE}$ proteins revealed at least five conserved regions. The two most striking regions were used for the design of the primers P1 and P2 (Fig. 1). With these two primers it was possible to amplify a fragment of 938 bp from chromosomal DNA of C. glutamicum. The size of the amplificate was as expected from the positions of the primers within the $n r d$ genes. This PCR product was sequenced and compared to known sequences in the databases (GenBank). The best findings were $75 \%$ identical bases with nrdE of Mycobacterium tuberculosis and $70 \%$ with $n r d E$ of Salmonella typhimurium. High similarity was also observed in the deduced amino acid sequence. This allowed us to conclude that the $938 \mathrm{bp}$ fragment is in fact a part of a $n r d E$ gene of C. glutamicum. Next, the PCR fragment was used as a probe for screening a cosmid library of C. glutamicum (Bathe et al., 1996). The four positive out of 576 cosmid clones were submitted to restriction analysis and the cosmid 810 was

\section{E. C. NrdA \\ s.t. NrdE \\ B.s. NrdE \\ M.t. NrdE}

Primer
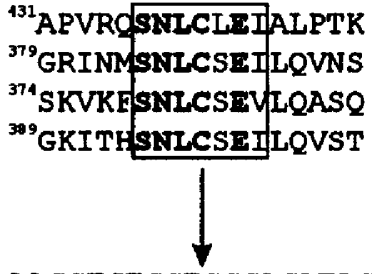

P1 5'-AACCTGTGCTCGGAGATAGC-3'

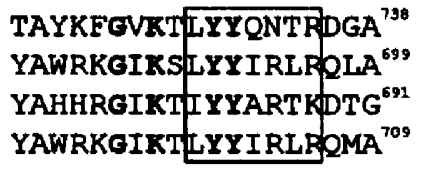

P2 $3^{\circ}$-GACATGATGTAGgCCGACGC-5'

Fig. 1. Design of degenerate primers for cloning the nrd genes of $C$. glutamicum from two highly conserved regions of known NrdA and NrdE proteins. The sequences of the primers were copied from the nucleotide sequence corresponding to the conserved regions, considering the codon usage of coryneform bacteria (Eikmanns, 1992) for variable positions. 
(a)

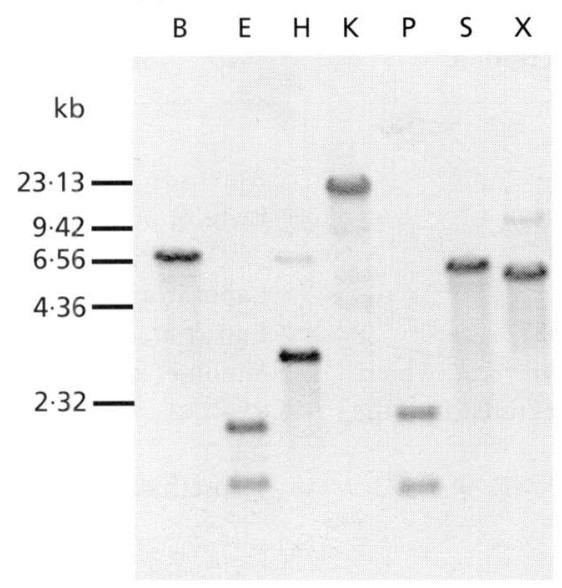

(b)

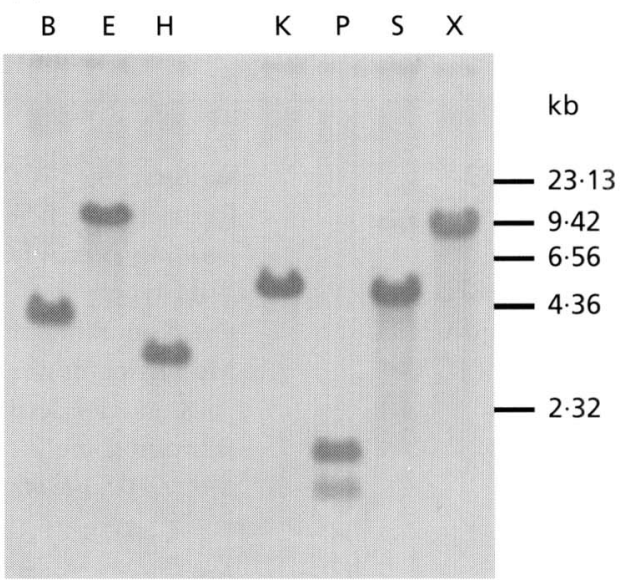

Fig. 2. Southern blots of cosmid 810 with the probes for the detection of nrdE (a) and nrdF (b) of C. glutamicum after digestion with different restriction endonucleases. The $n r d E$-containing fragments (a) obtained after digestion with $B a m H I, S a / l$ and $X b a l$ were used in comparison with sequence data for a rough calculation of the distance of nrdF to nrdHIE. B, BamHI; E, EcoRl; H, HindIII; K, Kpnl; P, Pstl; S, Sall; X, Xbal.

chosen for final cloning. From its $40 \mathrm{~kb}$ insert, restriction fragments were identified by Southern hybridization with the above PCR probe (Fig. 2a). Finally, a $4 \cdot 36 \mathrm{~kb}$ fragment obtained by restriction with $\mathrm{Xba \textrm {I }}$ and $\mathrm{BamHI}$ was ligated to pUC18, resulting in plasmid pWCG3 (Fig. 3 ), and used for sequencing. Analysis of its sequence showed that the complete $n r d E$ gene encoding the large catalytic subunit R1E of the C. glutamicum RNR was present on this $4.36 \mathrm{~kb} \mathrm{XbaI-BamHI}$ fragment. Two additional open reading frames, orientated in the same direction as $n r d E$, were identified as $n r d H(234 \mathrm{bp})$ and $n r d I$ (447 bp). However, the gene encoding the R2F subunit of the C. glutamicum RNR was not found on the $4.36 \mathrm{~kb} X b a \mathrm{I}-\mathrm{BamHI}$ insert of plasmid pWCG3 (Fig. 3).

A new tool for cloning of the missing gene was therefore required. Based on the high similarity between the $n r d E$ genes of C. glutamicum and M. tuberculosis (see Table 2 ) it was expected that the $n r d F$ genes of the two species would also be highly similar, and we decided to use the M. tuberculosis $n r d F$ gene as a hybridization probe. Yang et al. (1997) have described two $n r d F$ genes in $M$. tuberculosis. Only the probe derived from $n r d F 2$ hybridized with chromosomal DNA of C. glutamicum and was used for cloning (see Methods) of the identified fragments (Fig. 2b).

The exact distance between these genes and the orientation of $n r d F$ to the other three $n r d$ genes remained unknown because no common fragment for $n r d H I E$ and $n r d F$ was detected by Southern blotting (Fig. 2). This objective was achieved by bridging the gap between the genes of interest using PCR. For this purpose oligonucleotide primers were derived from sequences located at the ends of the $4.36 \mathrm{~kb} \mathrm{XbaI-BamHI}$ fragment and in the middle of the $n r d F$ gene (Fig. 3 ) in order to cope with the four possible arrangements. Using cosmid 810 as template for PCR only the reaction combining primers $b$ and $\mathbf{d}$ (Fig. 3) allowed the amplification of a fragment. Restriction analysis of this $3.2 \mathrm{~kb}$ product revealed the presence of all expected restriction sites known from sequence data. Based on this finding we calculated that $n r d F$ is located $3.1 \mathrm{~kb}$ downstream of $n r d E$ in the same orientation (Fig. 3). Thus, cosmid 810 was the only one containing the four genes nrdHIEF of C. glutamicum. 
Table 2. Percentages of identical amino acids in NrdE/F of $C$. glutamicum, $C$. ammoniagenes, M. tuberculosis, E. coli, S. typhimurium, M. genitalium and B. subtilis, and $\mathrm{NrdA} / \mathrm{B}$ of $E$. coli

The data represent the percentage of identical amino acids within the $\mathrm{NrdE} / \mathrm{NrdF}$ proteins. The following sequences were obtained from GenBank: Bacillus subtilis (B.s.), Z68500; C. ammoniagenes (C.a.), Y09572 and AF050168; C. glutamicum (C.g.), AF112535 and AF112536 (this work); E. coli (E.c.), AE000352; M. tuberculosis (M.t.), U41099 and U41100; Mycoplasma genitalium (M.g.), U39701; Salmonella typbimurium (S.t.), X73226; E. coli (E.c.) NrdAB, AE000313.

\begin{tabular}{|c|c|c|c|c|c|c|c|c|}
\hline Species & C. $g$. & C. $a$. & M. $t$. & E. c. & S. $t$. & M. $g$. & B. $s$. & $\begin{array}{c}E . c . \\
\text { NrdAB }\end{array}$ \\
\hline C. glutamicum & $100 / 100$ & $82 / 79^{*}$ & $78 / 74$ & $72 / 66$ & $70 / 65$ & $56 / 49$ & $48 / 42$ & $27 / 27$ \\
\hline C. ammoniagenes & & $100 / 100$ & $74 / 73$ & $69 / 64$ & $68 / 64$ & $54 / 54$ & $46 / 42$ & $26 / 26$ \\
\hline M. tuberculosis & & & $100 / 100$ & $71 / 71$ & $70 / 71$ & $57 / 51$ & $46 / 43$ & $27 / 28$ \\
\hline E. coli & & & & $100 / 100$ & $89 / 88$ & $54 / 51$ & $42 / 44$ & $26 / 26$ \\
\hline S. typhimurium & & & & & $100 / 100$ & $54 / 50$ & $44 / 45$ & $25 / 27$ \\
\hline M. genitalium & & & & & & $100 / 100$ & $43 / 34$ & $27 / 28$ \\
\hline B. subtilis & & & & & & & $100 / 100$ & $25 / 26$ \\
\hline E. coli NrdAB & & & & & & & & $100 / 100$ \\
\hline
\end{tabular}

In order to answer the question whether $n r d E$ and $n r d F$ exist only as a single copy on the C. glutamicum chromosome, total DNA of C. glutamicum was examined in additional hybridization studies with the original probes for cloning (938 bp PCR product, $n r d F 2$ of $M$. tuberculosis). Only one positive signal was observed for each gene probe even under non-stringent conditions.

\section{DNA sequence analysis of the nrdHIEF genes}

The 4363 bp insert of plasmid pWCG3 (Fig. 3) contains three open reading frames in the order $n r d H(234 \mathrm{bp})$, $n r d I$ (447 bp) and $n r d E$ (2124 bp). The $n r d F$ gene (1005 bp) is located $3 \cdot 1 \mathrm{~kb}$ downstream of $n r d E$ on the genome of C. glutamicum ATCC 13032. The G+C content of the $n r d$ genes ( $n r d H \quad 57.3 \mathrm{~mol} \%$; nrdI $49.9 \mathrm{~mol} \%$; $n r d E \quad 54.0 \mathrm{~mol} \%$; $n r d F \quad 51.7 \mathrm{~mol} \%$ ) is within the range described for genes of corynebacterial origin (Malumbres et al., 1993). Likewise, the codon usage of the $n r d H E F$ genes is in accordance with that reported for other genes of C. glutamicum (Eikmanns, 1992). An exception is the codon usage in $n r d I$ because AT-rich codons are preferred for the amino acids Asp, Gln, Lys, Phe and Tyr.

Starting signals for translation were identified for all four $n r d$ genes. Either $9 \mathrm{bp}$ or $11 \mathrm{bp}$ upstream of the ATG start codons of the genes nrdHIF there are purinerich octamers (AAGGGAAG) which fit well to the $3^{\prime}$ end of the 16S rRNA of C. glutamicum (GenBank Y12792) and may represent the Shine-Dalgarno sequence of the ribosome-binding site (RBS). The RBS of $n r d E$ probably contains the pentamer GGGAA as Shine-Dalgarno sequence located 8 bp upstream of the start codon GTG. A possible promoter region with a -10 sequence (TTTAAA) and a -35 sequence (TTTGTT) was found between positions 125 and 161 of the insert of pWCG3 (GenBank AF112535). Both sequences are rather similar to the consensus promoter sequence of C. glutamicum (Pátek et al., 1996). Upstream of $n r d I$ and $n r d E$ no promoter sequences were identified. This indicates that the three genes are transcribed as a unique polycistronic mRNA which is terminated by a palindromic region of $41 \mathrm{bp}$ located $7 \mathrm{bp}$ downstream of the stop codon of $n r d E$. A putative promoter of the $n r d F$ gene with a -10 sequence (TCTAAA) and a -35 region (TTTTGG) was found between the positions 282 and 308 of the $n r d F$ (GenBank AF112536) but no signal for transcriptional termination.

The deduced amino acid sequences of the $n r d E$ and the $n r d F$ genes from C. glutamicum strongly resemble those of $\mathrm{NrdE}$ and $\mathrm{NrdF}$ of $C$. ammoniagenes and $M$. tuberculosis. The percentages of identical amino acids are listed in Table 2 and clearly discriminate the $n r d$ genes of C. glutamicum from the $n r d A B$ system of E. coli encoding the prototype of the class I enzymes. The DNA sequence of the $n r d E$ and the $n r d F$ genes encoding the two subunits of the C. glutamicum RNR allowed us to calculate a molecular mass of $74.0 \mathrm{kDa}$ from the 707 amino acid residues of the NrdE protein (GTG as start codon) and of $34 \cdot 36 \mathrm{kDa}$ from the 334 residues of NrdF.

\section{Heterologous genetic complementation}

The availability of temperature-sensitive $n r d E$ mutants of C. ammoniagenes ATCC 6872 (Luo et al., 1997) offered the attractive possibility to demonstrate heterologous genetic complementation of these mutants with the $n r d E$ gene cloned from C. glutamicum. The $n r d E^{\text {ts }}$ strains $\mathrm{CH} 31$ and $\mathrm{CH} 33$ cannot grow at $37^{\circ} \mathrm{C}$ due to a defective large catalytic subunit of the Mn-RNR but are 
(a)

(b)

$\begin{array}{lllll}1 & 2 & 3 & 4 & 5\end{array}$

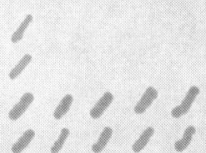

12345

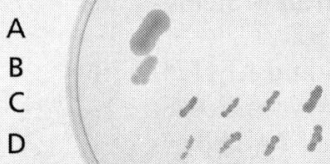

Fig. 4. Growth of the nrdE $E^{\text {ts }}$ mutants $\mathrm{CH} 31$ and $\mathrm{CH} 32$ of $\mathrm{C}$. ammoniagenes after genetic complementation with pWCG6 containing nrdE of $C$. glutamicum by RP4-mediated conjugation (Schafer et al., 1990). The cells were incubated at $27^{\circ} \mathrm{C}$ (a) and $37^{\circ} \mathrm{C}$ (b) for $2 \mathrm{~d}$. A1, C. ammoniagenes wild-type/pECM2; B1，C. glutamicum wild-type/pECM2; C1, CH31/pECM2; C2-5, CH31/pWCG6; D1, CH33/pECM2; D2-5, CH33/pWCG6.

able to grow under permissive conditions $\left(27^{\circ} \mathrm{C}\right)$. Upon conjugational transfer of plasmid pWCG6, which contains the nrdE gene of C. glutamicum, all transconjugants of $\mathrm{CH} 31$ and $\mathrm{CH} 33$ were able to grow at $37^{\circ} \mathrm{C}$ although with a lower growth rate than the wild-type. Transconjugants which had received the vector only did not grow at this non-permissive temperature (Fig. 4). The plasmids were reisolated from the complemented transconjugants and the control. Restriction analysis confirmed that pWCG6 was only present in those cells which were able to grow at $37^{\circ} \mathrm{C}$. Thus, restoration of growth in both $n r d E^{\text {ts }}$ mutants of $C$. ammoniagenes ATCC 6872 is caused by the $n r d E$ gene of C. glutamicum.

\section{DISCUSSION}

A divergent pattern of genomic organization is emerging in the Gram-positive bacteria from the increasing sequence information on chromosomal regions harbouring the $n r d E F$ genes obtained either from direct cloning (Jordan et al., 1996; Yang et al., 1994, 1997) or from genome sequencing projects (Fraser et al., 1995; Scotti et al., 1996; Himmelreich et al., 1996; Blattner et al., 1997; Cole et al., 1998). At present five different arrangements of the $n r d$ region are known (Fig. 5). Upon a broader view the basic underlying pattern corresponds well to the phylogenetic division of the Gram-positive bacteria into a low- and a high-GC branch. In the first group the $n r d E F$ genes are located on a contiguous stretch of DNA (Scotti et al., 1996; Jordan et al., 1996), even when rearranged by an unknown event as in Mycoplasma pneumoniae (Himmelreich et al., 1996). In the latter, now elevated to class rank as Actinobacteria (Stackebrandt et al., 1997), nrdF is distinctly separated from $n r d E$ with a gap increasing in the order C. ammoniagenes (1.2 kb, Fieschi et al., 1998; Oehlmann, 1998), C. glutamicum $(3 \cdot 1 \mathrm{~kb}$, this work) and Mycobacterium tuberculosis (1186 kb, Cole et al., 1998). The case of $M$. tuberculosis appears exceptional because this pathogen has a functional and a non-functional copy of the $n r d F$ gene (Yang et al., 1997).

The marked distance separating the genes $n r d H I E$ and $n r d F$ in C. glutamicum disproved our initial working hypothesis that both genes encoding the RNR of this species were easily accessible from a common genomic DNA fragment and in fact considerably delayed cloning of the gene of the small subunit. More lucky was our choice of primers for cloning the gene of the large catalytic subunit of RNR from C. glutamicum based on the fundamental assumption (Follmann, 1982) that the domains used here reflect a monophyletic origin of the substrate reduction and also a polyphyletic origin of the diverse radical-generating system (including subunits, also referred to as metallo-cofactors: Stubbe $\&$ van der Donk, 1995). For design of cloning primer P1 the region with the highest conservation of protein primary structure was exploited. The functionally important region SNLCXEI contains the essential cysteine residue, proposed to generate the radical which initiates the substrate reduction (Uhlin \& Eklund, 1994), and appears as a perfect target to design primers for cloning RNR genes. The region (LYYXR) used for design of primer P2 exists only in NrdA and NrdE proteins (Oehlmann, 1998) and strongly reflects the evolutionary adaptation of the class I and IV RNRs to the use of protein-bound metal for the generation of a stable radical. The two tyrosyl residues present in this region connect the longrange electron transfer from the small radical-containing subunit to the active centre in the large catalytic subunit (Ekberg et al., 1996). In addition, the primer design for the two regions of interest was facilitated by the codon usage in corynebacteria. These organisms prefer the GC-rich codons, especially for amino acids with only two possible codons (Eikmanns, 1992). Their frequency explains why the cloning primers used here (Fig. 1) had only three and four mismatches, respectively.

The function of the two small ORFs preceding $n r d E$ in C. glutamicum (this work) and in C. ammoniagenes (Fieschi et al., 1998) is not yet clear. The amino acid sequence deduced from the $n r d H$ gene $(77$ residues, $8 \mathrm{kDa}$ ) shows high similarity to $\mathrm{NrdH}$ of $E$. coli, Salmonella typhimurium and Lactococcus lactis and may function as a glutaredoxin, a specific electron donor, for the RNRs composed of NrdE and NrdF (Jordan et al., 1996; 1997). The hypothetical NrdI protein consists of 148 amino acid residues with a predicted molecular mass of $16 \cdot 4 \mathrm{kDa}$ but an unknown function in ribonucleotide reduction. Recently, in $S$. typhimurium a stimulatory effect of NrdI on the ribonucleotide reduction catalysed by NrdEF was reported (Jordan et al., 1997).

The sequence similarity of the $n r d E F$ genes within the Gram-positive bacteria parallels the phylogenetic branching (Fig. 6), i.e. the percentages of identical amino acids in the NrdE and the NrdF proteins of $C$. glutamicum are very high between members of the high- 


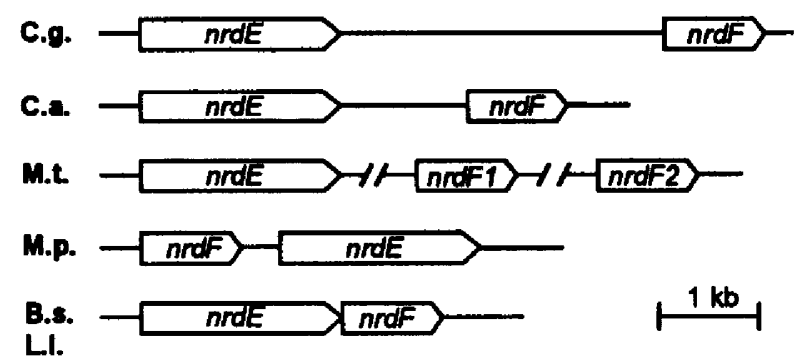

Fig. 5. Diverse arrangement of the nrdEF loci in Gram-positive bacteria. Taking $n r d H$ and $n r d l$ into account will additionally increase the diversity of the nrd loci. C.g., C. glutamicum (this work); C.a., C. ammoniagenes (Fieschi et al., 1998; Oehlmann et al., 1998); M.t., M. tuberculosis (Yang et al., 1994, 1997); M.p., Mycoplasma pneumoniae (Himmelreich et al., 1996); B.s., Bacillus subtilis (Scotti et al., 1996); L.l., Lactococcus lactis (Jordan et al., 1997).

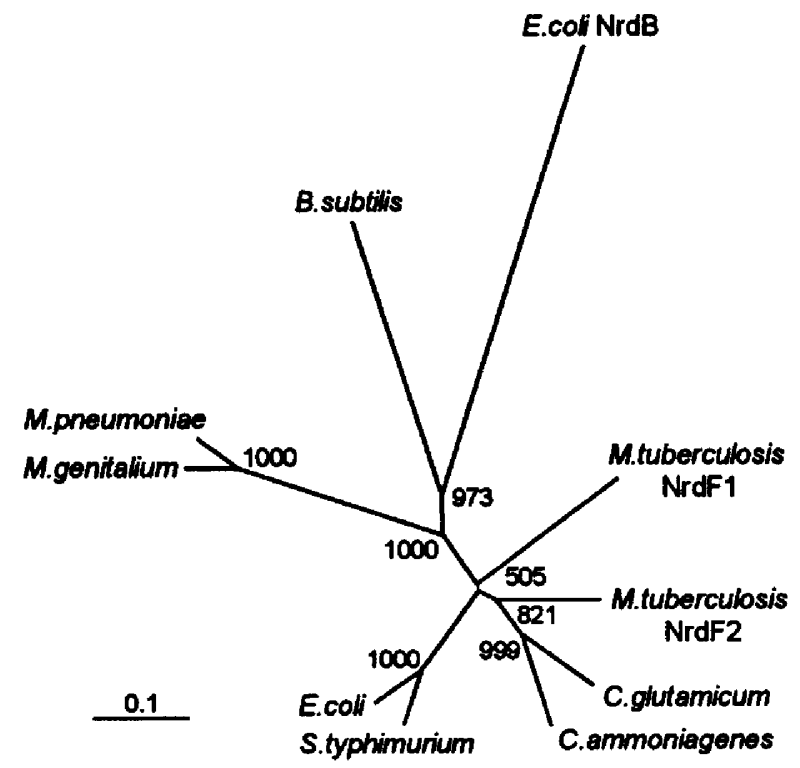

Fig. 6. Phylogenetic tree derived from known NrdF proteins and NrdB of $E$. coli as outlying sequence. CLUSTAL W (version $1.5 b)$ was used for sequence alignment. The tree was generated with 1000 bootstrap trials and the bootstrap values are labelled at the nodes. Sequence information was obtained from GenBank: Bacillus subtilis (P50621), C. ammoniagenes (AF050168), C. glutamicum (AF112536 for $n r d F$; this work), $E$. coli (AE000352), Mycobacterium tuberculosis (nrdF1 U41099; nrdF2 U41100), Mycoplasma genitalium (V39701), Mycoplasma pneumoniae (AE000050), Salmonella typhimurium (X73226) and E. coli nrdB (AE000313).

GC branch, and lower when compared to members of the low-GC branch (Table 2). The exceptionally high value of identical amino acids in the NrdEF proteins of C. glutamicum, E. coli (69\%, Blattner et al., 1997) and S. typhimurium $(70 \%$, Jordan et al., 1994) suggests a horizontal gene transfer of the $n r d E F$ genes from the Actinobacteria to a common ancestor of $E$. coli and $S$. typhimurium when taking into account that these genes are absent in the closely related Haemophilus influenzae (Fleischmann et al., 1995).

The alignment of NrdF from C. glutamicum and C. ammoniagenes with $\mathrm{NrdB}$ of $E$. coli (Fig. 7) reveals that the functional constraints for the evolution of the metal and radical containing subunit have conserved specific domains. Thus, the tyrosyl residue in position 120 of the C. glutamicum NrdF equivalent to the $T \mathrm{yr}_{114}$ of the $C$. ammoniagenes $\mathrm{NrdF}$ (Oehlmann et al., 1998) corresponds to the $\mathrm{Tyr}_{122}$ bearing the organic radical in the E. coli Fe-RNR (Nordlund et al., 1990). This alignment suggests that both corynebacterial NrdF proteins contain a tyrosyl radical. In addition, the constraints of the radical mechanism required for reduction of ribonucleotides appear to be very strong in both the $\mathrm{Fe}$ - and the Mn-enzyme, i.e. the three residues building a hydrophobic pocket probably necessary for the stabilization of the radical in the Fe-RNR (Ormö et al., 1995) are also present in the NrdF proteins of C. ammoniagenes and C. glutamicum. Likewise, all amino acids proposed to be involved in the long-range electron transfer through the $\mathrm{NrdB}$ protein are conserved in the corynebacterial proteins (Fig. 7) as are the residues responsible for binding the iron in the E. coli RNR (Nordlund et al., 1990; Sjöberg, 1997). All these probably functionally important residues are present not only in the corynebacterial RNRs but also in all known NrdEF proteins with the exception of the genus Mycoplasma. In comparison to the primary structure of $\mathrm{NrdB}$ there are several gaps in the amino acid sequence of the $\mathrm{NrdF}$ proteins. Modelling of the corynebacterial NrdF proteins (Oehlmann, 1998) reveals that these deletions occur in the peripheral shell and do not change the coordination of the interior $\alpha$-helices containing the conserved residues, which bind the iron in the $\mathrm{NrdB}$ protein (Nordlund et al., 1990). However, the sequence alignment does not allow inference of the metal specificity of the C. glutamicum RNR. Recent biochemical data from ICP-MS measurements of R2F from C. glutamicum revealed that the active protein contains manganese but no iron (Abbouni et al., 1999). This supports the assignment of the C. glutamicum enzyme to class IV of the RNR classification scheme of Stubbe \& van der Donk (1995). Thus, a second manganese enzyme is added to the C. ammoniagenes RNR, which clearly contains manganese (Willing et al., 1988; Griepenburg et al., 1998; Fieschi et al., 1998). In this work hybrid Mn-RNRs were generated in vivo by the successful genetic complementation between the resident $n r d F$ gene in the C. ammoniagenes $n r d E^{\text {ts }}$ mutants and the $n r d E$ gene introduced from the C. glutamicum wildtype, indicating the cooperation of the heterologous subunits. This contrasts with the previous failure to establish heterologous biochemical complementation with combinations of the C. ammoniagenes Mn-RNR and the E. coli Fe-RNR (Willing et al., 1988).

A possible major role for the residues in the second coordination sphere determining the metal specificity of the RNRs has been extensively discussed by Fieschi et al. 


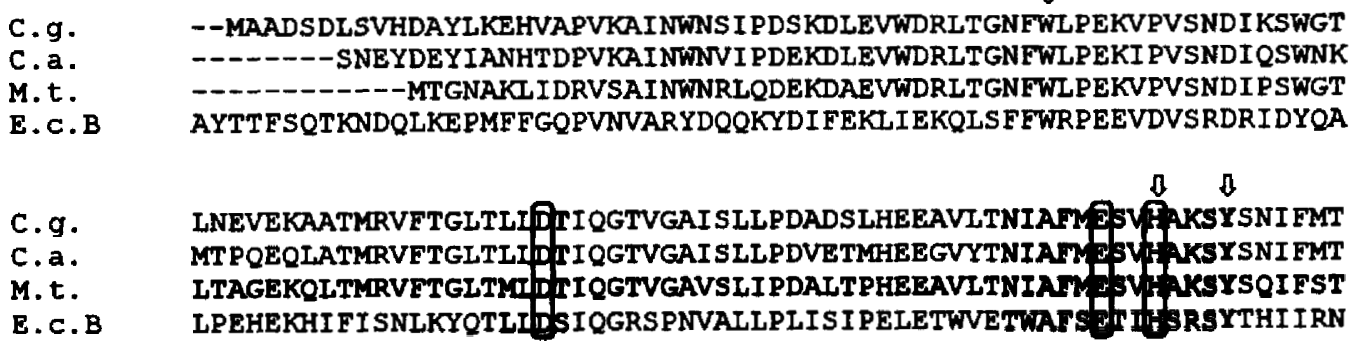

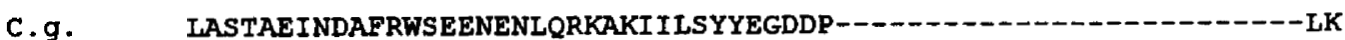

c.a.

M. $t$.

E.C.B

c. g.

c.a.

M.t.

E. C.B

C.g.

c.a.

M. $t$.

E.C.B

C.g.

C.a.

M.t.

E.C.B

IASTPQINEAFRWSEENENLQRKAKI IMSYYNGDDP-C.

ICSTAE I DDAFRWSEENRNIQRKAEIVIQYYRGDEP-_...

IVNDPSV--VEDDIVTNEQIQKRAEGISSYYDELIEMTSYWHLLGEGTHTVNGKTVTVSLRELK

\section{0}

RKI-----ASVIIESFLFYSGFYLPMYWSSHSKLTNTADVIRLIIRDEATRGYYIGYKYOKAVA KKV-----ASTLI ESFLFYSGFYLPMYLSSRAKLTNTADI IRLI I RD SSWLEYYIGYKYQQGVK RKV-----ASTII EFLFYSGFYLPMYWSSRAKLTNTADMIRLIIRL EAVI GYYIGYKFORGLA KKLYLCLMSVNAI EAIRFYVSFACSFAFAERELMEGNAKI IRLIARLEALITGTQHMLNLLRS

KETP----ERQEELKEYTFDLLYDLYDNETQYSEDLYDD---LGWTEDVK-RFLRYIANKALNN KLSE----AEQEEYKAYTFDLMYDLYENEI EYTEDIYDD---LGWTEDVK-RFLRYNANKALNN 274 LVDD----VTRAELKDYTYELLFELYDNEVEYTQDLYDE---VGLTEDVK-KFLRYNANKALMN 270 GADDPEMAE IAEECKOECYDLFVQAAQQEKDWADYLFRDGSMIGLNKDILCQYVEYITNIRMOA

a LGYEGLFPADETKVSPNILSALSPNADENHDFFSGSGSSYVIGKAENTEDDDWDF---LGYEGLFPTDETKVSPAIISSLSPNADENHDFFSGSGSSYVIGKAEDTTDDDWDF---LGYEALFPRDETDVNPAI LSALSPNADENHDFFSGSGSSYVIGKAVVTEDDDWDF - - - VGLDLP FQTR--SNPI PWINTWLVSDNVQVAPQEVEVS SYLVGQIDSEVDTDDLSNFQL

Fig. 7. Alignment of NrdF proteins of $C$. glutamicum, $C$ ammoniagenes and $M$. tuberculosis with NrdB of the Fe-RNR of $E$. coli. The tyrosine residue probably carrying the organic radical is in bold. The proposed metal ligands are boxed. The downward-pointing arrows indicate amino acids involved in the electron transfer; residues of the hydrophobic pocket thought to stabilize the radical are labelled with an exclamation mark (!). For accession numbers see the legend to Fig. 6.

(1998) based on observations with other manganese enzymes, cambialistic or not (Beyer et al., 1991; GraeffWohlleben et al., 1997; Gabbianelli et al., 1997; Boldt et al., 1997). Such a concept implies that the metal centre of the corynebacterial NrdF proteins has not been a direct target of the evolutionary drift ultimately leading to the divergence of the $n r d B$ and $n r d F$ genes. This view may change with advancing knowledge of the direct ligands in the metal centre of the unusual RNRs of $C$. glutamicum and C. ammoniagenes.

\section{ACKNOWLEDGEMENTS}

The authors appreciate the constant support by and helpful discussions with A. Pühler (University of Bielefeld) and his coworkers J. Kalinowski, B. Bathe and L. Wehmeier, especially during screening the cosmid library of C. glutamicum ATCC 13032. We are grateful to P. Sander, Medical High School of Hannover, for providing DNA of the avirulent strain Mycobacterium tuberculosis HR37 and sequencing of the initial PCR products. We thank Dr J. Meens of our laboratory for help during sequencing of the corynebacterial $n r d E F$ genes and for critical reading of the manuscript. This work was supported by a grant from the Deutsche Forschungsgemeinschaft to G. Auling.

\section{REFERENCES}

Abbouni, B., Oehlmann, W. \& Auling, G. (1999). Ribonucleotide reductase of Corynebacterium glutamicum ATCC13032 is a class IV enzyme. BIOspektrum (ISSN 0947-0867) special issue, p. 79 (abstracts of the VAAM Meeting, March 7-10, Göttingen).

Auling, G. \& Follmann, H. (1994). Manganese-dependent ribonucleotide reduction and overproduction of nucleotides in coryneform bacteria. In Metal Ions in Biological Systems, vol. 30, Metalloenzymes Involving Amino Acid-residues and Related Radicals, pp. 131-164. Edited by H. Sigel \& A. Sigel. New York: Marcel Dekker.

Ausubel, F. A., Brent, R., Kingston, R. E., Moore, D. D., Seidemann, J. G., Smitz, J. A. \& Struhl, K. (1990). Current Protocols in Molecular Biology. New York: Greene Publishing and Wiley Interscience.

Bathe, B., Kalinowski, J. \& Pühler, A. (1996). A physical and genetic map of the Corynebacterium glutamicum ATCC 13032 chromosome. Mol Gen Genet 252, 255-265.

Beyer, W.s Imlay, J. \& Fridovich, I. (1991). Superoxide dismutases. Prog Nucleic Acid Res Mol Biol 40, 221-253.

Birnboim, H. C. \& Doly, J. (1979). A rapid alkaline extraction procedure for screening recombinant plasmid DNA. Nucleic Acids Res 7, 1513-1523.

Blattner, F. R., Plunkett G., III, Bloch, C. A. \& 14 other authors 
(1997). The complete genome sequence of Escherichia coli $\mathrm{K}-12$. Science 277, 1453-1474.

Boldt, Y. R., Whiting, A. K., Wagner, M. L., Sadowsky, M. J., Que, L. \& Wackett, L. P. (1997). Manganese(II) active site mutants of 3,4-dihydroxyphenylacetate 2,3-dioxygenase from Arthrobacter globiformes strain CM-2. Biochemistry 36, 2147-2153.

Carlson, J., Fuchs, J. A. \& Messing, J. (1984). Primary structure of the Escherichia coli ribonucleotide diphosphate reductase. Proc Natl Acad Sci USA 81, 42944297.

Cole, S. T., Brosch, R., Parkhill, J. \& 39 other authors (1998). Deciphering the biology of Mycobacterium tuberculosis from the complete genome sequence. Nature 393, 537-544.

Eikmanns, B. J. (1992). Identification, sequence analysis, and expression of a Corynebacterium glutamicum gene cluster encoding the three glycolytic enzymes glyceraldehyde-3-phosphate dehydrogenase, 3-phosphoglycerate kinase, and triosephosphate isomerase. J Bacteriol 174, 6076-6086.

Ekberg, M., Sahlin, M., Eriksson, M. \& Sjobberg, B.-M. (1996). Two conserved tyrosine residue in protein $\mathrm{R} 1$ participate in an intermolecular electron transfer in ribonucleotide reductase. $J$ Biol Chem 271, 20655-20659.

Fieschi, F., Torrents, E., Toulokhonova, L., Jordan, A., Hellmann, U., Barbe, J., Gibert, I., Karlsson, M. \& Sjobberg, B.-M. (1998). The manganese-containing ribonucleotide reductase of Corynebacterium ammoniagenes is a Class Ib enzyme. J Biol Chem 273, 4329-4337.

Fleischmann, R. D., Adams, M. D., White, O. \& 37 other authors (1995). Whole-genome random sequencing and assembly of Haemophilus influenzae. Science 269, 496-512.

Follmann, H. (1982). Deoxyribonucleotide synthesis and the emergence of DNA in molecular evolution. Naturwissenschaften $69,75-81$.

Fraser, C. M., Gocayne, J. D., White, O. \& 26 other authors (1995). The minimal gene complement of Mycoplasma genitalium. Science 270, 397-403.

Gabbianelli, R., Battistoni, A., Polticelli, F., Meier, B., Schmidt, M., Rotilio, G. \& Desideri, A. (1997). Effect of Lys175 mutation on structure function properties of Propionibacterium shermanii superoxide dismutase. Protein Eng 10, 1067-1070.

Graeff-Wohlleben, H., Killat, S., Banemann, A., Guiso, N. \& Gross, R. (1997). Cloning and characterization of a Mn-containing superoxide dismutase (SodA) of Bordetella pertussis. J Bacteriol 179, 2194-2201.

Griepenburg, U. (1998). Das stabile freie Radikal und das mononukleare Manganzentrum im CA2-Protein der Ribonucleotid-Reduktase aus Corynebacterium ammoniagenes ATCC 6872. $\mathrm{PhD}$ thesis, University of Hannover, Germany.

Griepenburg, U., Lassmann, G. \& Auling, G. (1996). Detection of a stable free radical in the B2 subunit of the manganese ribonucleotide reductase (Mn-RNR) of Corynebacterium ammoniagenes. Free Radical Res 261, 473-481.

Griepenburg, U., Kappl, R., Hüttermann, J. \& Auling, G. (1998). A divalent metal site in the small subunit of the manganesedependent ribonucleotide reductase of Corynebacterium ammoniagenes. Biochemistry 37, 7992-7996.

Harder, J. (1993). Ribonucleotide reductases and their occurrence in microorganisms: a link to the RNA/DNA transition. FEMS Microbiol Rev 12, 273-292.

Himmelreich, R., Hilbert, H., Plagens, H., Pirkl, E., Li, B. C. \& Herrmann, R. (1996). Complete sequence analysis of the genome of the bacterium Mycoplasma pneumoniae. Nucleic Acids Res 24, $4420-4449$
Hogenkamp, H.P.C. \& McFarlan, S. (1984). Nature and properties of the bacterial ribonucleotide reductases. Pharmacol Ther 23, 393-404.

Jerpseth, B., Greener, A., Short, J. M., Viola, J. \& Kretz, P. L. (1993). New restriction minus derivates of XL1-Blue E. coli cells. Stratagies 6, 24.

Jordan, A. \& Reichard, P. (1998). Ribonucleotide reductases. Annu Rev Biochem 67, 71-98.

Jordan, A., Gibert, I. \& Barbé, J. (1994). Cloning and sequencing of the genes from Salmonella typhimurium encoding a new bacterial ribonucleotide reductase. J Bacteriol 176, 3420-3427.

Jordan, A., Pontis, E., Aslund, F., Hellman, U., Gibert, I. \& Reichard, P. (1996). The ribonucleotide reductase system of Lactococcus lactis. J Biol Chem 271, 8779-8785.

Jordan, A., Aslund, F., Pontis, E., Reichard, P. \& Holmgren, A. (1997). Characterization of Escherichia coli NrdH. J Biol Chem 272, 18044-18050.

Kinoshita, S. (1985). Glutamic acid bacteria. In Biology of Industrial Microorganisms, pp. 115-142. Edited by A. L. Demain $\&$ N. A. Solomon. London: Benjamin/Cummings.

Lammers, M. \& Follmann, H. (1983). The ribonucleotide reductases: a unique group of metalloenzymes essential for cell proliferation. Struct Bond 54, 27-91.

Liebl, W. (1992). The genus Corynebacterium-nonmedical. In The Prokaryotes: a Handbook on the Biology of Bacteria, vol. 2, pp. 1157-1171. Edited by A. Balows, H. G. Trüper, M. Dworkin, W. Harder \& K.-H. Schleifer. New York: Springer.

Liebl, W. \& Schein, B. (1990). Isolation of restriction deficient mutants of Corynebacterium glutamicum. In DECHEMA Biotechnology Conferences, vol. 4, pp. 323-327. Edited by D. Behrens \& J. Krämer. Weinheim: VCH Verlagsgesellschaft.

Luo, C.-H., Hansen, J. \& Auling, G. (1997). Temperature-sensitive mutants of Corynebacterium ammoniagenes ATCC6872 with a defective large subunit of the manganese-containing ribonucleotide reductase. Arch Microbiol 167, 317-324.

Malumbres, M., Gil, J. A. \& Martín, J. F. (1993). Codon preference in corynebacteria. Gene 134, 15-24.

Nordlund, P., Sjöberg, B.-M. \& Eklund, H. (1990). Threedimensional structure of the free radical protein of ribonucleotide reductase. Nature 345, 593-598.

Oehlmann, W. (1998). Klonierung der Gene der Ribonucleotid Reduktase von Corynebacterium ammoniagenes und Corynebacterium glutamicum. PhD thesis, University of Hannover, Germany.

Oehlmann, W., Griepenburg, U. \& Auling, G. (1998). Cloning and sequencing of the $n r d F$ gene of Corynebacterium ammoniagenes ATCC 6872 encoding the functional metallo-cofactor of the manganese-ribonucleotide reductase (Mn-RNR). Biotechnol Lett 20, 483-488.

Oka, T., Udagawa, K. \& Kinoshita, S. (1968). Unbalanced growth death due to depletion of $\mathrm{Mn}^{2+}$ in Brevibacterium ammoniagenes. J Bacteriol 96, 1760-1767.

Ormö, M., Regnström, K., Wang, Z., Que, L., Jr, Sahlin, M. \& Sjoberg, B.-M. (1995). Residues important for radical stability in ribonucleotide reductase from Escherichia coli. J Biol Chem 270, 6570-6576.

Pátek, M., Eikmanns, B. J., Pátek, J. \& Sahm, H. (1996). Promoters from Corynebacterium glutamicum: cloning, molecular analysis and search for a consensus motif. Microbiology 142, 1297-1309.

Reichard, P. (1993). From RNA to DNA, why so many ribonucleotide reductases? Science 260, 1773-1777. 
Sambrook, J., Fritsch, E. F. \& Maniatis, T. (1989). Molecular Cloning: a Laboratory Manual, 2nd edn. Cold Spring Harbor, NY: Cold Spring Harbor Laboratory.

Schäfer, A., Kalinowski, J., Simon, R., Seep-Feldhaus, A. H. \& Puhler, A. (1990). High frequency conjugal plasmid transfer from Escherichia coli to various gram-positive coryneform bacteria. $J$ Bacteriol 172, 1663-1666.

Schäfer, A., Kalinowski, J. \& Pühler, A. (1994). Increased fertility of Corynebacterium glutamicum recipients in intergenic matings with Escherichia coli after stress exposure. Appl Environ Microbiol 60, 756-759.

Scotti, C., Valbuzzi, C., Perego, M., Galizzi, A. \& Albertini, A. M. (1996). The Bacillus subtilis ribonucleotide reductase is similar to the second class I NrdE/NrdF enzymes of Enterobacteriaceae. Microbiology 142, 2995-3004.

Simon, R., Priefer, U. \& Puhler, A. (1983). A broad host range mobilization system for in vivo genetic engineering: transposon mutagenesis in gram negative bacteria. Bio/Technology 1, 84-87.

Sjöberg, B.-M. (1997). Ribonucleotide reductases - a group of enzymes with different metallosites. Struct Bond 88, 139-173.

Stackebrandt, E., Rainey, F. A. \& Ward-Rainey, N. L. (1997). Proposal for a new hierarchic classification system, Actinobacteria classis nov. Int J Syst Bacteriol 47, 479-491.
Stubbe, J. \& van der Donk, W. (1995). Ribonucleotide reductases: radical enzymes with suicidal tendencies. Chem Biol 2, 793-801.

Uhlin, U. \& Eklund, H. (1994). Structure of ribonucleotide reductase protein $\mathrm{R} 1$. Nature 370, 533-539.

Willing, A., Follmann, H. \& Auling, G. (1988). Ribonucleotide reductase of Brevibacterium ammoniagenes is a manganese enzyme. Eur J Biochem 170, 603-611.

Yang, F., Lu, G. \& Rubin, H. (1994). Isolation of ribonucleotide reductase from Mycobacterium tuberculosis and cloning, expression, and purification of the large subunit. J Bacteriol 176, $6738-6743$.

Yang, F., Curran, S. C., Li, L.-S., Avarbock, D., Graf, J. D., Chua, M.-M., Lu, G., Salem, J. \& Rubin, H. (1997). Characterization of two genes encoding the Mycobacterium tuberculosis ribonucleotide reductase small subunit. J Bacteriol 179, 6408-6415.

Yanisch-Perron, C., Vieira, J. \& Messing, J. (1985). Improved M13 phage cloning vectors and host strains: nucleotide sequences of M13mp18 and pUC vectors. Gene 33, 103-119.

Received 31 December 1998; revised 15 March 1999; accepted 31 March 1999. 